\title{
LEADER'S ABILITY TO ENSURE THE ESSENTIAL MILITARY STUDY GROUP COHESION LEVEL
}

\section{Olena Volobuieva}

Leaders are people who do the right thing. Managers are people who do things right.... A profound difference. Jeorge Washington (Hugh Rawson and Margaret Miner, 2006) ${ }^{1}$

\section{INTRODUCTION}

The professionalization process of the future officer as the future military specialist begins since the very first day of entering the higher military educational establishment when the professional competence formation of every individual in the particular study group is started and the group as human system develops under the tough control of the group leader and the number of well-educated lectures, teachers and trainers. In this particular well-organized system the professional individual development of group members and the very group as an organized system take place step by step and the role of group cohesion as one of the principle factors which determines the professional growing of the future specialists is of vital importance.

The current personality development paradigm of the professional training of the personnel of all the categories of the State Border Guard Service of Ukraine requires from every unit leader to create the necessary didactic-psycho-pedagogical conditions for the effective communication while carrying out moral-psychological providing of the border guards professional activity.

The investigation topicality of this problem is stipulated by the necessity of rise in effectiveness and quality of the borderguard officers professional training, search of the successful vectors of optimization of the moralpsychological providing system, on the one hand, and on the other hand, by the not enough development level of the cadets - the future borderguard officers organizational abilities. In this context it is essential to emphasize the importance of taking into the unit leader's account the socio-

\footnotetext{
${ }^{1}$ Jeorge Washington, copybook, Rules of Civility @ Decent Behavior In Company and Conversation, The Oxford Dictionary of American Quotations / selected and annotating by Hugh Rawson and Margaret Miner, Copyright, 2006, Published by Oxford University Press, Inc. 198 Madison Avenue, New York, New York, p. 403.
} 
psychological determinants of group influence upon the cadets. The proper knowledge of these determinants gives the opportunity to create the motive influences while carrying out the moral-psychological providing with the purpose of actualization of the real possibilities of every group member within the objective measures of individual's potential.

In our investigation we have used the Gordon L. Lippitt's conceptual approach to the individual development of the future officer as the particular ways by which the certain cadet - the future border guard officer learns, matures, and grows as a consequence of the analyzed life experiences on the grounds of 1) positive interaction with the internal and external environments; 2) the participation of the planned education, training and development activities of either a formal and informal nature ${ }^{2}$ (Lippitt, 1982a).

\section{Study group leader's role in professional development of the future borderguard officers}

The scientific sources analysis results testify about the fact that a great number of works have dedicated to the aspects of the leaders role in the professional development process of the future specialists.

Marcus Buckingham and Curt Coffman in their book attract our attention to the fact that manager's role is the catalyst role. They found the manager's function to be the speeder of the reaction between two substances, particularly between individuals' talents and the company's goals ${ }^{3}$ (Buckingham \& Coffman, 2005).

While investigating the peculiarities of professional development of the specialist in the defence environment, Alex Alexandrou and Roger Darby (2006) emphasize that: 1) success in managing people in the defence environment often rests on a manager's interpersonal skills and 2) the manager's ability to create an effective working environment ${ }^{4}$ (Alexandrou $\&$ Darby (2006).

What is important for us is on the basis of revealing the cohesion nature to investigate the survey results (we have conducted in the military

${ }^{2}$ Lippitt, Gordon L. (1982). Organization renewal. A Holistic Approach to Organization Development, Second Edition. Printice - Hall, Inc., Englewood Cliffs, New Jersey, the USA, 418 p., p. XIV.

${ }^{3}$ Buckingham Marcus and Coffman (2005). First, Break the Rules. What the World's Greatest Managers Do Differently. Pocket Books. London-Sydney-New-York-Toronto, Great Britain, Simon @ Schuster UK Ltd. A CBS Company, 303 p., p. 54).

${ }^{4}$ Alexandrou Alex and Darby Roger, 2006, Human resource management in the defense environment. Managing Defense in a Democracy. Edited by Laura R. Cleary and Teri McConville, Routledge: Taylor @ Francis Group, London and New York, pp. 157-178. 
environment in order to 1) determine the study group leader's understanding of their role in the process of forming the group team and 2) to be professionally competent as for sticking military study group together and rise in effectiveness group members' professional activity. That is why the aim of the article is to reveal the investigation results we have achieved within the framework of conducting the special worked out survey on the cohesion level of the study groups in the military environment. After having analyzed the survey results the further directions of the organizational abilities of the military study groups' leaders' development will be defined.

Before carrying out the study for us it was absolutely important to understand the very nature of the group cohesion as the "truly multidisciplinary and interdisciplinary phenomenon ${ }^{5}$ (Lippitt, 1982b). For instance, Henry Kellerman investigates group cohesion from the psychological and psychoanalytical points of view; Jürk W. Tuber considers group cohesion on the grounds of the microbiological theory; Karsten J. Struhl in his group cohesion study reveals the small group processes peculiarities from the philosophical view; Leo Silber dedicates his group cohesion investigation to the aspects of the larger social context; David R. Roth analyses the aspects of social cohesion; John H. Crook studies ethological features of social processes in individual; Robert A. Ravich researches the nature of cohesion in intimate relationships and family structures $^{6}$ (Kellerman et. al.,1981a).

According to the New Oxford Advanced Learner's (2005a) 1) the term "cohesion" means: (n) the action or fact of forming a united whole; 2) the term "cohesive" (adj). characterized by or causing cohesion. ${ }^{7}$

As we consider the cohesion as a phenomenon within the context of group dynamics, first of all, it is important to understand the very group nature and its life functioning on the grounds of the wide variety of the theoretical approaches or orientations to group dynamics. They are the following: 1) Lewin's field theory; 2) interaction theory (according to this theory group is considered to be a system of interacting individuals); 3) the systemic approach (i.e. the group as a miniature social system); 4) sociometry (interpersonal choices viewed as binding groups of people together); 5) psychoanalytic conceptions (motivational and defensive

${ }^{5}$ Lippitt, Gordon L. (1982). Organization renewal. A Holistic Approach to Organization Development, Second Edition. Printice - Hall, Inc., Englewood Cliffs, New Jersey, the USA, 418 p., p. XXVI.

6 Group Cohesion, 1981, Theoretical and Clinical Perspectives. Edited by Henry Kellerman, Grune\& Stratton, Inc. New York.

7 The New Oxford Advanced Learner's Dictionary, Second Edition, Published by Oxford University Press, 2005, Inc. 198 Madison Avenue, New York, New York,. 2051 p., p. 330 
processes within the individual); 6) cognitive theory (Gestalt emphasis on individual perceptual organization of one's environment ${ }^{8}$ (Weston, 1998a).

\section{Leaders's consciosness as the sense of "we-ness"}

In our investigation we have taken into our consideration the fact that consciousness according to Robert S. Feldman is the awareness of the sensation, thoughts and feelings being experienced at a given moment The scientist finds consciousness to be one's subjective understanding of both the environment around us and our private internal world ${ }^{9}$ (Feldman, 1999a).

For leader it is essential to remember that cohesiveness according to Robert Kreitner and Angelo Kinicki is a sense of "we-ness" which helps to stick group members together They have defined two types of cohesiveness, particularly: 1) socio-emotional cohesiveness (is the sense of togetherness that develops when individuals derive emotional satisfaction from group participation); 2) instrumental cohesiveness (the sense of togetherness that develops when group members are mutually dependent on one another because they believe they could not achieve the group's goal by acting separately ${ }^{10}$ (Kreitner \& Kinicki, 1998).

In the study of groups, the two key variables are the following: 1) cohesiveness (i.e. the sum of the forces that bind an individual to the group, it is vital in determining the group's influence over its members. Research has shown its close interrelationship with other variables, such as communication and conformity; 2) locomotion (it signifies the group movement towards a desired goal) ${ }^{11}$ (Weston, 1998b).

\section{Military study group cohesion and its influence upon the organization of communication in the system «leader - group members»}

It goes without saying that while carrying out the psychological influence upon the personnel professional activity every leader has to take into her/his consideration the fact that the important index (indicator) of the interpersonal relationships between the personnel (group members) is the very cohesion level.

\footnotetext{
${ }^{8}$ Weston Louise C. (1998). Group Dynamics. The Encyclopedia Americana - International Edition, Grolier Incorporated, Volume 13, 922 p., p. 517.

${ }^{9}$ Feldman Robert S. (1999). Understanding Psychology. Fifth Edition McGrow-Hill, the USA, 774 p., p., 146).

${ }^{10}$ Kreitner Robert and Kinicki Angelo (1998) Organizational Behavior. Fourth Edition, Irwin/McGrow-Hill, Copyright, 670 p., p.402.

11 Weston Louise C. Group Dynamics. The Encyclopedia Americana - International Edition, Grolier Incorporated, Volume 13, 1998, 922 p., p. 517).
} 
S. A. Bagretsov, V. M. L'vov, V. V. Naumov, K. M. Oganyan in their research proved that cohesion is one of the main group indicators. It characterizes the degree of predominance of affections over dislikes of every group member towards the rest of the group members ${ }^{12}$ (Bagrecov S. A. et. al., 1999a).

The certain study author's experience, some observations results (we use the naturalistic observation study ${ }^{13}$ (Goodwin, 2005a) in order to study the behaviors of the study group members as they act in their 24 hours environment: in the barracks, at the lessons and trainings and at night time during the shifts when the cadets carry out their various guard duties; the analysis results of the moral up-bringing influence, training results, questionnaire of the unit leaders, teachers, officers and the cadets, testify about the fact that nowadays the moral-psychological providing of the border guard professional activity not always reaches the final objective. That is why the aims of our study: are the following 1) to investigate the psychological determinants of cohesion of border guard cadets study group as the small group with the external status (that influence upon the organization of the professional activity of the personnel of the State Border Guard Service of Ukraine); and 2) on the basis of the investigation results to determine the ways of leaders' organizational abilities development which, in its turn, will rise in cohesion level in the study groups in the conditions of the higher military educational establishments; 3 ) to work out the practical recommendations on the increasing the group cohesion level for the study group leaders.

It is absolutely essential for study group leaders to have some knowledge of the cohesion expressiveness level in the particular study group of this psychological phenomena because the effectiveness of the various joint activity forms of group members and development of the necessary professional skills and habits depend greatly on it.

Moreover, for successful study group management it is of vital importance to devote some time and attention to acquiring some knowledge on group socio-psychological processes that form group cohesivenessans also revealing these phenomena in the group formation dynamics in the context of professional training of the future border guard officers. In its turn it gives a leader the opportunity: 1) to provide cohesive cooperation and

${ }^{12}$ Bagrecov S. A. (1999). Diagnostika socialno-psihologicheskih harakteristik malyh grupp $s$ vneshnim statusom [Diagnostics of social-psychological characteristics of small groups with the external status] / S. A. Bagrecov, V. M. Lvov, V. V. Naumov, K. M. Oganyan. - SPb. :Lan, izdatelstvo Sankt-Peterburgskogo universiteta MVD Rossii, 1999. - 640 s. [in Russian], p. 126.

${ }^{13}$ Goodwin C. James Research in Psychology. Methods and Design. Fourth Edition, Wiley. John Wiley@ Sons, Inc., the USA, 556 p., 2005. p. 393). 
effective mutual activity of group members in order to form the essential level of professional competence, i.e. the abilities to carry out the professional duties up to the level.

In the context of our research it is important for us to use Henry Kellerman (1981) conceptual view as for the term group cohesion, particularly the scientist finds this phenomenon to be related to 1) the affiliation needs of individuals; 2) the particular punitive structure of groups - that is, deep group cultural structures; 3) the nature of the leadership; 4) group process $)^{14}$ (Kellerman \& et. al., 1981b).

\section{Survey research sociometrical evaluation of study group cohesion level in the conditions of the higher military educational establishment}

In order to evaluate the moral-psychological climate and group processes in the study group in the conditions of the higher military educational establishment the sociometrical study has been conducted. Sociometry is the quantitative study and measurement relationships within a group of people ${ }^{15}$ (The New Oxford Advanced Learner's Dictionary, 2005b) and in the research we used Jacob L. Moreno's Quantitative Method for measuring social relationships. (In our study we have used the sociometry (a set of methods created by J. L. Moreno to study the interpersonal relationships ${ }^{16}$ (Hale, 2009) for measuring the cohesion level_the study groups. Sociometry has given us the opportunity to evaluate the study group cohesion degree, to determine the group members social status and also to reveal the micro groups) ${ }^{17}$.

We also have taken into our consideration that groups are human system in which the members are interdependent and share an identity. All groups have a structure and boundaries that both separate and join them in their environment ${ }^{18}$ (Longres, 1995a) social control mechanisms, and socially

\footnotetext{
14 Group Cohesion, 1981, Theoretical and Clinical Perspectives. Edited by Henry Kellerman, Grune\& Stratton, Inc. New York, 465 p. , p. 4.

${ }^{15}$ The New Oxford Advanced Learner's Dictionary (2005), Second Edition, Published by Oxford University Press, Inc. 198 Madison Avenue, New York, 2051 p., p.1610.

${ }^{16}$ Hale Ann E. Moreno's Sociometry: Exploring Interpersonal Connection. Group. Vol. 33, No. 4, Psychodrama (December 2009 pp.347-358), Published by Eastern Group Psychotherapy Society, (p. 347) (www.jstor.org/stable/41719254?seq=1).(accessed 10.12.2019).

${ }^{17}$ Rayigorodskyi S. V. (2006). Mnogourovnevyj lichnostnyj oprosnik «Adaptivnost» (MLOAM) A.G. Maklakova i S.V. Chermyanina / Prakticheskaya psihodiagnostika. Metodiki i testy [Multilevel personal questionnaire "Adaptation" (MLO-AM. Practical psychodiagnostics. Methods and tests]. Uchebnoe posobie. Red. i sost. Rajgorodskij D.Ya. - Samara. [in Russian] $672 \mathrm{p}$.

${ }_{18}$ Longres John F. Human Behavior in the Social Environment. Second Edition. F. E. Peacock Publishers, Inc. Itasca, Illinois. Copyright, 1995, 568 p.,p.318.
} 
organized interaction patterns ${ }^{19}$ (Huge, William, Helmreich, McCord, 1992). That is why in our investigation we follow the idea of C. James Goodwin about the fact that the very survey research is based on the simple idea that if you want to find out what people think about some topic, just ask them. According to C. James Goodwin's definition a survey is a structured set of questions or statements given to a group of people to measure their attitudes, beliefs, values, or tendencies to act ${ }^{20}$ (Goodwin, 2005b).

And for our study was absolutely important to take into our consideration the fact that as systems, the groups have the typical attributes. Let us consider them in more details. The investigation results of John F. Longres indicate that groups have seven attributes ${ }^{21}$ (Longres, 1995b), particularly:

1) independence, i. e. each group has the particular collection of individuals and each its member is unique, but at the same time, all group members are interdependent;

2) structure, i.e. a group has the specific internal organization consisting the particular working/service agreements or norms and a division of labor marked by roles and statutes;

3) identity, i.e. (every group is self-conscious entity and emphasizes that group members see themselves as "us";

4) boundaries, i.e. within a group the boundaries are marked physically by the space it occupies; from the psychological point of view the group boundaries are marked by the personalities of the group members; and socially the boundaries are characterized as having its sense of self and its special norms and traditions ${ }^{22}$ (Longres,. 1995c);

5) organization as a holon (according to the conceptualization of the holon it means the idea that every social system is simultaneously a whole and a part of a whole ${ }^{23}$ (Longres, 1995d) i.e. a group is at the same time a whole_in itself and part of another whole; it exists within a social environment;

6) openness, i.e. a group, like individual, is an open system that cannot exists independently of her or his social environment and must interact with it;

\footnotetext{
${ }^{19}$ Hugh Lena F., Helmreich William B., McCord William (1992). Contemporary Issues in Society, McGrow-Hill,, 556 p., p. 31.

${ }^{20}$ Goodwin C. James Research in Psychology. Methods and Design. Fourth Edition, Wiley. John Wiley@ Sons, Inc., the USA, 556 p., (2005), p. 402).

${ }^{21}$ Longres John F. Human Behavior in the Social Environment. Second Edition. F. E. Peacock Publishers, Inc. Itasca, Illinois. Copyright, 1995, 568 p., p. 318.

${ }^{22}$ Longres John F. (1995). Human Behavior in the Social Environment. Second Edition.

F. E. Peacock Publishers, Inc. Itasca, Illinois. Copyright, 568 p, pp. 319-20.

${ }^{23}$ Longres John F. (1995). Human Behavior in the Social Environment. Second Edition. F. E. Peacock Publishers, Inc. Itasca, Illinois. Copyright, 568 p. , p. 46.
} 
7) dynamism, i.e. it is typical of a group that: 1) there is the independence among the group members and 2) there is openness with the environment (that is why a group is dynamic ${ }^{24}$ (Longres, 1995e) and in this context we have to stress and it is important for our study that the term "group dynamics" means the processes involved when people in a group interact with each other ${ }^{25}$ (The New Oxford Advanced Learner's Dictionary, 2005c),

In his research Rafael Steinberg (1975) mentioned that depending on the nature of the organization, the very exacting performance in the particular organization the organization must have clear communication channels through which its goals and commands can be transmitted ad acknowledged... and it must keep a sharp eye on its own decision-making process. Rafael Steinberg points out that the organization's decisions determine its future ${ }^{26}$ (Steinberg, 1975).

In the system of the professional training it is of vital importance to remember about the group support within the framework of the study group development in general and individual development in particular. The very group experience provides numerous healing factors that are intrinsic to the group process (such as the thoughts validation, emotions, and stress reactions ${ }^{27}$ (Willis Dan, 2014).

Moreover, as we conducted the cohesion study in the military environment, while carrying out the research we took into our consideration the fact that it is typical of groups in the military environment to have the "nature of compliance" This term was suggested by Amatai Etzioni. According to the "nature of compliance" the scientist gives three categories of organizations, namely: 1) coercive, normative utilitarian ${ }^{28}$ (Etzioni, 1971).

Rafael Steinberg (1975a) stresses that in the military organizations everyone knows her/his place the individual knows who reports to him, and to whom these individual reports in turn. Commissioned officers receive their appointments from a higher authority. In his research the scientist attracts our attention to the fact that in peacetime a volunteer army is primary utilitarian. Some soldiers may enlist for patriotic reasons but one of them probably sign up for the pay, to see the world or to get an education. And he

\footnotetext{
${ }^{24}$ Longres John F. (1995). Human Behavior in the Social Environment. Second Edition. F. E. Peacock Publishers, Inc. Itasca, Illinois. Copyright, 568 p., p. 320.

${ }^{25}$ The New Oxford Advanced Learner's Dictionary (2005), Second Edition, Published by Oxford University Press, , Inc. 198 Madison Avenue, New York, 10016, 2051 p.

${ }^{26}$ Steinberg Rafael (1975). Man and the Organization. Human Behavior, Time-Life Books, New York, 176 p., p.66.

27 Willis Dan (2014). Bulletproof Spirit. The First Responder's Essential Resource for Protecting and Healing Mind and Heart. New World Library, the USA. 14 Pamaron Way, Novato, California, Copyright, 2014, - 230 p., p. 90.

${ }^{28}$ Amatai Etzioni (1971) A Comparative Analysis of Complex Organizations, 366 p.
} 
makes the conclusion that: 1) in the military organization the compliance system shifts drastically when the guns start firing; 2) no army could pay its soldiers enough to compensate for the risks and hardships of war; troops must be motivated by other methods in order to appeal to patriotism ${ }^{29}$ (Rafael Steinberg, 1975b).

The set of sociometrical methods were used at the end of the special period of the cadets - the future officers when they studied together for the definite period of time - with the purpose of group dynamics evaluating in general and the military unit cohesion level in particular. We have conducted our study in the period when the cadets had known each other in a proper well for the particular period of time while studying and also carrying out the professional duties after classes.

In our research we have taken into our consideration the results of the processes involved when the cadets in a group interact with each other, that is we have studied group dynamics.

The social and interpersonal relations are connected greatly that is why the study groups of their nature are considered to be the combination of relationships within a group of cadets (collaboration, competition, cohesion, compatibility, agreement and harmony, friendship, dislike, hostility etc.) and personal character traits and qualities which influence the psychological peculiarities of communication process within the particular study group (openness, politeness, respect, unsociability, independence, sensitiveness, adherence to principle, honesty, responsibility etc.).

The dominant relationships in the group determine its structure and sociometry - is the most effective method of studying the structure of nonformal interpersonal relationships which are typical of the study group, evaluating of popularity (non-popularity) of all the group members, revealing of non-formal group leader, micro-groups, determining the sociopsychological compatibility (non-compatibility) of group members in the conditions of the team work/activity.

1. The sociometry method is rather informative and on the other hand it is not complicated. Such method gives us the opportunity to reveal the individual's desire (or unwillingness) for interaction with other people in the concrete conditions, to reveal the leader (leaders) and also to determine the group organization level ${ }^{30}$ (Bagrecov et. al. ,1999b). Our survey research

${ }^{29}$ Steinberg Rafael (1975) Man and the Organization. Human Behavior, Time-Life Books, New York, 176 p. p.67-69).

${ }^{30}$ Bagrecov S. A. (1999). Diagnostika socialno-psihologicheskih harakteristik malyh grupp $s$ vneshnim statusom [Diagnostics of social-psychological characteristics of small groups with the external status] / S. A. Bagrecov, V. M. Lvov, V. V. Naumov, K. M. Oganyan. - SPb. :Lan, izdatelstvo Sankt-Peterburgskogo universiteta MVD Rossii, 1999. - 640 s. [in Russian]. 
was based on the simple idea that if you want to find out what people think about the certain topic in our case - the level of interpersonal relations, just ask them ${ }^{31}$ (Goodwin, 2005c). We conducted our research in the form of questionnaire of all the group members with the purpose of study the individual opinions the all group members as for the aspects we are interested in, particularly each individual was asked the certain question on the her/his personal attitude towards the other group members.

Before writing the survey, the instructor explains the group members (the respondents) the purpose of the survey and the ways of doing it and only after that they filled it in written form.

While carrying out the sociometric investigation it is essential to take into one's account the following conditions (aspects):

the survey study must be conducted by the instructor - a person who is unknown to group members and who asks the group to perform a particular task;

a group has to consist of the cadets who have been known each other due to reconcile activity (of the period no less than 2-3 months);

the number of group members of each study group have to be limited strictly (in our study: it is the structural unit);

the condition, which suggested for consideration, is to be formulated in such a way, that it is clear for everyone and gives the opportunity interpersonal relationships at the individual level.

In our research we used the sociomatrix in the form of the statistical table, where the positive and negative choices are located (we used the same number of the tables as the number of the study group members).

The sociomatrix analysis gave us the opportunity to evaluate the member groups' answers according to the number of positive and negative choices we had achieved; to reveal micro groups of persons with mutual positive choices, conflict pairs and persons with no authority in the groups.

While evaluating the sociometrical results we calculated the sociometrical personal and group indexes that characterize the relationships in the particular study group quantitatively. The personal indexes permitted us to reveal the certain individual' characteristics and qualities in the group quantitatively. We described the group characteristics with the help of the group indexes in general.

It is essential to point out that the personal sociometrical indexes and the indexes of group members' emotional expansivity belong to the sociometrical status indexes. The sociometrical status index 1) reflects the

31 Goodwin C. James (2005). Research in Psychology. Methods and Design. Fourth Edition, Wiley. John Wiley @ Sons, Inc., the USA, 556 p., p. 402. 
general (favorable or not favorable one) position of the particular cadet - the future border guard officer in the group; the group attitude towards the certain cadet; 2) characterizes the level of the cadet's potential leadership.

The index of the emotional expansivity characterizes the individual's attitude towards the group and needs for communication and collaboration activity.

The sociometrical status index of the certain individual in the group is calculated by the formula

$$
C=\frac{(B+)+(B-)}{n-1},
$$

Where $C$ - the sociometrical status of the certain group member; $(B+)-$ the sum of positive choices, which had been got by the certain group member (the index is calculated in the vertical sociomatrix column); $(B-)-$ the sum of the negative choices, received by the certain group member; $n-$ the number of the group members, who participated in the investigation.

On the basis of these results we can compare the group members according to their authority and influence upon the group behavior.

The individual emotional expansivity index is calculated by the formula

$$
E=\frac{(A+)+(A-)}{n-1},
$$

where $E$ - the emotional expansivity of the certain group member; $(A+)$ - the positive choices made by the certain group member as for the group members; $(A-)$ - the negative choices made by the certain group member as for the group members; $n$ - the number of the group members.

The group members sociometrical status and emotional expansivity indexes (i.e. the individual indexes), can be served as the basis for the comparison with the other group members.

The cohesion index and conflict index belong to the group indexes.

The group cohesion index is measured by the ratio of the number of made mutual choices towards the number of the theoretically possible mutual positive relationships:

$$
G=\frac{D+}{n \cdot(n-1)},
$$

where $G$ - the group cohesion index; $(D+)$ - the total number of the mutual positive choices; $n-$ the number of the group members. 
The index permits to compare the different groups according to the cohesion degree. The conflict index is determined in the same way but only according to the results of the negative choices.

$$
K=\frac{S-}{n \cdot(n-1)},
$$

where $K-$ the group conflict index; $S--$ the total number of mutual negative choices; $n$ - the number of the group members.

In our research we have used the $100 \%$ scale of the evaluation of the group cohesion index for the general analysis of the study groups development level, particularly:

up to $25 \%$ - the lowest level of the study group development (this level is characterized by the first cohesion signs);

25-50\% - the law study group development level;

51-75\% - the middle study group development level;

$76-100 \%$ - the high study group development level.

Thus, the main purpose of the sociometrical method usage was to evaluate the cohesion level in the unit group and on the basis of the study results to create the special program aimed at the increasing level of the cohesion level of the military units with the positive moral-psychological atmosphere, which is of vital importance for the effective carrying out leader's professional tasks within the framework of upbringing and training the cadets - the future border guard officers according to the up-to-date requirements of the higher military education.

Taking into our consideration all the above-mentioned peculiarities and principles we conducted the detailed investigation and analysis of the cohesion index in the study groups of the National Academy of the State Border Guard Service of Ukraine named after Bohdan Khmelnitsky (NASBGSU) where the professional training of the future border guard officers is conducted. The research was held in the period of 2018 and 2019 years.

As the sociometric investigation is to be conducted only after the sixmonth period of the study group formation, and taking into our account the fact that in the second year of cadets' studying the specialization redistribution takes place, the third-year cadets were chosen for the investigation (2018 year). After that in a year we conducted the analogical investigation and analysis in the same study groups (2019 year).The statistical testing results are given in Table 1. (The cohesion index has been converted into the $100 \%$ scale for the calculations convenience). 
With the help of T- Wilcoxon criterion, we examined whether the cohesion level displacement occurred or not ${ }^{32}$ (Sydorenko, 2000).

Table 1

Statistical investigation of cohesion level changes in the cadets' study groups (the third and fourth years of studying at NASBGSU)

\begin{tabular}{|c|c|c|c|c|c|c|c|}
\hline \multirow[b]{2}{*}{ № } & \multirow[b]{2}{*}{$\begin{array}{c}\text { Study } \\
\text { group } \\
\text { number }\end{array}$} & \multirow[b]{2}{*}{$\begin{array}{l}\text { Number } \\
\text { of cadets }\end{array}$} & \multicolumn{2}{|c|}{ Cohesion level } & \multirow[b]{2}{*}{$t_{4} t_{3}$} & \multirow[b]{2}{*}{$\left|t_{4} t_{3}\right|$} & \multirow[b]{2}{*}{$\begin{array}{c}\text { Chang } \\
\text { e rank } \\
\text { numbe } \\
\mathbf{r}\end{array}$} \\
\hline & & & $\begin{array}{c}t_{3}(\text { the } \\
\text { 3-d } \\
\text { studyin } \\
\text { g year) } \\
2017\end{array}$ & $\begin{array}{c}t_{4} \\
\text { (the 4-th } \\
\text { studying } \\
\text { year) } \\
2018\end{array}$ & & & \\
\hline 1 & 241 & 19 & 75 & 80 & 5 & 5 & 6,5 \\
\hline 2 & $242 / 1$ & 19 & 80 & 79 & -1 & 1 & 1 \\
\hline 3 & $242 / 2$ & 10 & 82 & 97 & 5 & 5 & 6,5 \\
\hline 4 & $243 \mathrm{k}$ & 10 & 93 & 98 & 5 & 5 & 6,5 \\
\hline 5 & $243 t$ & 15 & 95 & 97 & 2 & 2 & 2,5 \\
\hline 6 & 244 & 25 & 74 & 81 & 7 & 7 & 11 \\
\hline 7 & $341 / 1$ & 10 & 81 & 79 & -2 & 2 & 2,5 \\
\hline 8 & $341 / 2$ & 13 & 84 & 81 & -3 & 3 & 4 \\
\hline 9 & 342 & 33 & 88 & 94 & 6 & 6 & 9,5 \\
\hline 10 & 441 & 19 & 91 & 96 & 5 & 5 & 6,5 \\
\hline 11 & $\begin{array}{l}541 / 1, \\
541 / 2 \\
\end{array}$ & $12+5$ & 84 & 91 & 6 & 6 & 9,5 \\
\hline \multicolumn{2}{|c|}{ Total } & 190 & & & 35 & 66 & 66 \\
\hline
\end{tabular}

Groups 541/1 and 541/2 had been united before the investigation because the cadets from the both groups had spent the considerable part of their time together and moreover the biggest part of the subjects they had studied were learned at the same time.

The results of the investigation testify about the fact that the cohesion level in almost all the study groups (with the exception of three study groups $242 / 1,341 / 1,341 / 2$ ) is high and in general during the year the changes as for increasing groups cohesion level occurred. T-Wilcoxon criterion was chosen for the statistical verification and all the restrictions of which had been observed. The statistical hypotheses have been formulated in the following way:

the main hypothesis: $H_{0}$ - the displacement intensity as for the increasing of the cohesion levels does not exceed the displacement intensity as for reducing;

${ }^{32}$ Sidorenko E. V. (2000). Metodyi matematicheskoy obrabotki v psihologii [Methods of Mathematical Processing in Psychology. S-Pb.: Rech Publ. [in Russian]. 350 p. 
the competitive hypothesis: $H_{1}$-the displacements intensity as for cohesion levels increasing exceeds the displacement intensity as for reducing.

The empirical criterion value has been calculated by the formula:

$$
T_{\text {eMn }}=\sum R_{r}
$$

Where $R_{r}$ - rank valued is placements with the most seldom sign.

In our case it is marked by another color in the table 1 (particularly in the groups 242/1, 341/1, 341/2).

We compared the received empirical value criterion with the critical value of the relative level of the statistical relevance (1.5):

$$
T_{\kappa p}^{*}=\left\{\begin{array}{l}
13(p \leq 0,05) \\
7(p \leq 0,01)
\end{array}\right.
$$

In our case $-* T_{\text {eMn }}=1+2,5+4=7,5$ permits to assert that the displacements intensity as for the increasing of the cohesion level is more than the displacements intensity as for the reducing. In this case the mistake obviousness is not more than $5 \%$.

\section{CONCLUSION}

Having investigated the peculiarities of the individual relationships in the study groups in the conditions of the higher military educational establishment as for the determining the certain cohesion level of the cadets - future border guard officers on the grounds of the survey study we have obtained the results we are interested in, namely:

1) the specific aspects of the study group life as the nature and requirements of leadership, the different roles of the group members, friendship or attraction in the groups, and the process of making decisions in the groups;

2) the research also has provided us with the essential information on the cadets' individual communications and relationships among members in the particular study groups, and the hidden forces that influence the way the groups members do and behave in the group;

3 ) we have got the new ideas about the aspects on the high morale and effective action in groups which are so important for providing the effective professional development of the cadets - the future borderguard officers.

The leader's role in the process of developing the study group members' professional abilities is of vital importance. 
And it is important for the senior officers and the study group leaders together with teachers to organize the training system in such a way that cadets feel some comfort and help them to achieve professional competence by making sure that they have skills necessary to attain the desired goals ${ }^{33}$ (Thomas et. al., 2000). The very environment influences upon the group structure $^{34}$ (Show, p.243). For creating well-organized study environment in groups it is necessary to remember about the fact that the group members must not be psychologically distressed. So it is the fundamental concerns of the positive psychology ${ }^{35}$ Furnham, 2008).

As groups develop and hold the norms, expectations regarding behavior appropriate to the group ${ }^{36}$ (Feldman, 2009b). It is of vital importance to take into study group leader's consideration the very peculiarities of human attitudes, opinions and behaviors of all the study group members in the process of teaching and training activity management ${ }^{37}$ (Mashbyts, 2019) on the grounds of high responsibility for intellectual activity ${ }^{38}$, In this context we have taken into our account the fact that groups are not simply collections of individuals. Groups are systems ${ }^{39}$ (Longres, 1995f) and for a study group leader it is essential to understand that upper and lower limits on practical problem-solving are determined by a set of underlying basic competencies and by the interactions among these competencies the manner in which practical problem-solving develops is restricted by the development of the basis cognitive abilities. The variations within these limits are determined by individual historical factors (e.g. education, job complexity, etc. $^{40}$ (Blanchard-Fields \& Hess, 1996), individual, age and gender peculiarities.

33 Education Psychology (2000). Effective Teaching, Effective Learning. Krtochwill Thomas R., Cook Jan Littlefield, Travers John F. Third Edition. Mc Grow-Hill Higher Education, the USA. - 631 p., p. 366.

${ }^{34}$ Shaw Marvin E. (1976), Group Dynamics. The Psychology of Small Group Behavior, McGraw-Hill Book Company, the USA, 464 p., p. 18.

${ }^{35}$ Furnham Adrian (2008). 50 ideas you really need to know. Psychology, Quercus Edition Ltd, 55 Baker Street, $7^{\text {th }}$ Floor, South Block, London, W1U8EW, Printed and bound in China, 208 p., pp. 52-53.

${ }^{36}$ Feldman (2009). Robert S. Understanding psychology. McGrow-Hill, 2009, 622 p.,p.595.

37 Mashbyts Yu. I. (2019). Psykholohichni mekhanizmy I tekhnolohiia navchannia [Psychological mechanisms and technology of teaching]. K.: Interservis [in Ukrainian], 208 p. p. 133

${ }^{8}$ Smulson M.(2019) The significance of problem-solving in the professional activity. Psychological Basis of Professional Problem Solving : collective monograph / M. Smulson, M. Tomchuk, A. Chornyi, V. Demskyi, A. Makovskyi, Anatolii Yakymchuk, T. Scherbana, O. Volobuieva. - Lviv-Toruń : Liha-Pres, 2019. - 178 p. pp.1-21. (ISBN 978-966-397-152-0).

${ }^{39}$ Longres John F. (1995). Human Behavior in the Social Environment. Second Edition.

F. E. Peacock Publishers, Inc. Itasca, Illinois. Copyright, 568 p., p. 319.

${ }^{40}$ Fredda Blanchard-Fields, Thomas M. Hess. Perspectives on Cognitive Change in Adulthood and Aging, McGrow-Hill, 1996, 537 p., p. 333. 


\section{SUMMARY}

The article deals with the investigation results of the leader's ability to form the essential cohesion level in the study groups of the cadets - future border guard officers. The survey study results testified about the necessity of the further border guard officers' organizational abilities development in the system of the professional training in the conditions of the military educational establishment, the essential level of which is the basis of the proper study group cohesion level. In its turn it ensures the effectiveness of the professional training and as a result, - the necessary level of the future border guard officers professional competence formation.

The results of the study have indicated that not all the study group leaders have the necessary level of the organizational abilities and as the consequences the cohesion level in the three experimental groups were not up-to-the level. That is why it is essential to work out the special program on the purposeful development of the organizational abilities of the border guard officers and the cadets - the future border - guard officers. The welldeveloped organizational abilities and proper knowledge of the individual, age and gender group members peculiarities will make it is possible for the study group leaders to form the essential level of the professional competence of the cadets and as a result they will carry out the professional activity successfully after having graduate.

The size of the article does not permit to reveal all the investigation esults. The further investigation ways of the problem of the leaders' organizational abilities development in the military environment are the following: 1) studying the role of the leader's consciousness in the process of the effective study group management and development; 2) working out the Program on the future borderguard officers' organizational abilities development.

\section{REFERENCES}

1. Alexandrou Alex and Darby Roger (2006). Human resource management in the defense environment. Managing Defense in a Democracy. Edited by Laura R. Cleary and Teri McConville, Routledge: Taylor @ Francis Group, London and New York, pp.157-178.

2. Bagrecov S. A. (1999). Diagnostika socialno-psihologicheskih harakteristik malyh grupp s vneshnim statusom [Diagnostics of socialpsychological characteristics of small groups with the external status] / S. A. Bagrecov, V. M. Lvov, V. V. Naumov, K. M. Oganyan. - SPb. :Lan, izdatelstvo Sankt-Peterburgskogo universiteta MVD Rossii, 1999. - 640 s. [in Russian].

3. Blanchard-Fields Fredda, Hess Thomas M. (1996). Perspectives on Cognitive Change in Adulthood and Aging. McGrow-Hill, 537 p. 
4. Buckingham Marcus and Coffman (2005). First, Break the Rules. What the World's Greatest Managers Do Differently, Pocket Books. London-Sydney-New-York-Toronto, Great Britain, Simon@ Schuster UK Ltd. A CBS Company, 303 p.

5. Education Psychology (2000). Effective Teaching, Effective Learning. Kratochwill Thomas R., Cook Jan Littlefield, Travers John F. Third Edition. Mc Grow-Hill Higher Education, the USA. - 631 p.

6. Etzioni Amatai. (1971). A Comparative Analysis of Complex Organizations.

7. Feldman Robert S. (1999). Understanding Psychology. Fifth Edition. McGrow-Hill, the USA, $774 \mathrm{p}$.

8. Furnham Adrian (2008). 50 ideas you really need to know. Psychology, Quercus Edition Ltd, 55 Baker Street, $7^{\text {th }}$ Floor, South Block, London, W1U8EW, Printed and bound in China, 208 p.

9. Goodwin C. James (2005). Research in Psychology. Methods and Design. Fourth Edition, Wiley. John Wiley @ Sons, Inc., the USA, 556 p.

10. Group Cohesion. Theoretical and Clinical Perspectives. Edited by Henry Kellerman (1981), Grune\& Stratton, Inc. New York, 465 p.

11. Hale Ann E. Moreno's Sociometry: Exploring Interpersonal Connection. Group. Vol. 33, No. 4, Psychodrama (December 2009, pp. 347-358), published by Eastern Group Psychotherapy Society, (p. 347) (www.jstor.org/stable/41719254?seq $=1$ ), accessed on the $10^{\text {th }}$ of December 2019.

12. Hugh Lena F., Helmreich William B., McCord William (1992). Contemporary Issues in Society, McGrow-Hill,, 556 p.

13. Kreitner Robert and Kinicki Angelo (1998). Organizational Behavior. Fourth Edition, Irwin/McGrow-Hill, Copyright, 670 p.

15. Lippitt, Gordon L. (1982). Organization renewal. A Holistic Approach to Organization Development, Second Edition. Printice - Hall, Inc., Englewood Cliffs, New Jersey, the USA, -418 p.

16. Mashbyts Yu. I. (2019). Psykholohichni mekhanizmy I tekhnolohiia navchannia [Psychological mechanisms and technology of teaching]. K.: Interservis [in Ukrainian], 208 p. p. 133.

17. Longres John F. (1995). Human Behavior in the Social Environment. Second Edition. F. E. Peacock Publishers, Inc. Itasca, Illinois. Copyright, $568 \mathrm{p}$.

18. Rayigorodskyi S. V. (2006). Mnogourovnevyj lichnostnyj oprosnik «Adaptivnost» (MLO-AM) A.G. Maklakova i S.V. Chermyanina / Prakticheskaya psihodiagnostika. Metodiki i testy [Multilevel personal questionnaire "Adaptation" (MLO-AM. Practical psychodiagnostics. Methods and tests]. Uchebnoe posobie. Red. i sost. Rajgorodskij D.Ya. Samara. [in Russian] 672 p. 
19. Sidorenko E. V. (2000). Metodyi matematicheskoy obrabotki $v$ psihologii [Methods of Mathematical Processing in Psychology]. SPb.: Rech Publ. [in Russian].

20. Shaw Marvin E. (1976), Group Dynamics. The Psychology of Small Group Behavior, McGraw-Hill Book Company, the USA, 464 p.

21. Smulson M. (2019) The significance of problem-solving in the professional activity. Psychological Basis of Professional Problem Solving : collective monograph / M. Smulson, M. Tomchuk, A. Chornyi, V. Demskyi, A. Makovskyi, Anatolii Yakymchuk, T. Scherbana, O. Volobuieva. - LvivToruń : Liha-Pres, 2019. - 178 p., pp.1-21.

20. Steinberg Rafael (1975) Man and the Organization. Human Behavior, Time-Life Books, New York, 176 p.

21. The New Oxford Advanced Learner's Dictionary (2005), Second Edition, Published by Oxford University Press, , Inc. 198 Madison Avenue, New York, 10016, $2051 \mathrm{p}$.

22. The Oxford Dictionary of American Quotations / selected and annotating by Hugh Rawson and Margaret Miner (2006), Copyright, Published by Oxford University Press, Inc. 198 Madison Avenue, New York, New York, 10016, 898 p.

23. Weston Louise C. (1998). Group Dynamics. The Encyclopedia Americana - International Edition, Grolier Incorporated, Volume 13, 922 p., p. 517.

24. Willis Dan (2014). Bulletproof Spirit. The First Responder's Essential Resource for Protecting and Healing Mind and Heart. New World Library, the USA. 14 Pamaron Way, Novato, California, Copyright, 2014, 230 p.ON

\section{Information about the author: Olena Volobuieva,}

Doctor of Sciences in Psychology, Professor,

Deputy Rector for Research, National Academy of the State Border Guard Service of Ukraine named after Bohdan Khmelnytskyi 46 Shevchenko str., Khmelnytskyi, 29003, Ukraine

ORCID ID: orcid.org/0000-0003-4010-6398 helen_volobueva@ukr.net 